\title{
Influence of Dehydration Stress on the Adrenal Glands of Two Semi-domesticated Avian Species
}

\author{
Kakali De* and Asok Ghosh*
}

\begin{abstract}
The effects of water deprivation on the adrenal glands were studied in two avian species, the pigeon and the house sparrow. Dehydration failed to produce any change in the histology of the adrenal gland of the house sparrow, while, in the pigeon, medullary lobes were constricted and myeloid tissues increased. Biochemical observations showed that dehydration resulted in the decrease of both norepinephrine $(34 \%)$ and epinephrine $(50 \%)$ from the adrenal medulla of the house sparrow, whereas, in the pigeon, only epinephrine (45\%) decreased following water deprivation. Water deprivation caused an increase of glandular corticosterone both in the pigeon $(375.7 \%)$ and in the house sparrow $(336.7 \%)$. The present observations illustrate that participation of corticosterone in dehydration is possibly universal in birds. By contrast, the differential responsiveness of the catechol hormones in these two species was noted. However, the adrenomedullary catecholamine response during water deprivation was independent of the NE: E ratio of both species. To explain this, the reno-physiological status and concentration of other hormones in these birds needs to be considered.
\end{abstract}

Keywords: Dehydration stress, norepinephrine, epinephrine, corticosterone, pigeon, House Sparrow, adrenal gland

\section{Introduction}

Activation of hypothalamo-hypophysial-adrenal axis is generally accepted as an operational definition of stress. Deprivation of water has been reported to serve as a severe stress (Freeman, 1976; Beuving and Vonder, 1978). The role of adrenal cortex in situation of water deprivation in mammals is fairly well documented. Water deprivation increases the plasma corticosterone concentration in rats (Levine and Coover, 1976; Gray et al. 1978; Johnson and Levine, 1978; Wilkinson et al. 1982). In the avian group, conflicting reports are available relating to dehydration-induced changes of corticosterone content. Plasma corticosterone increases following dehydration in turkey (Brown, 1961), chicken (Freeman et al. 1983; Harvey et al. 1985), fowl (Beuving and Vonder, 1978) and duck (Harvey et al. 1981), while in quail (Kobayashi et al. 1980) and fowl (Arad et al. 1985), water-deprivation failed to alter the plasma corticosterone level.

The role of adrenal medulla in counteracting dehydration stress is yet to be investigated in mammals. However, in the avian group, it has been reported that epinephrine plays a pivotal role to counteract the dehydration stress in the pigeon (Ghosh and Sitaraman 1976) and the Japanese quail (Kobayashi et al. 1980), whereas in the parakeet, both norepinephrine and epinephrine are required to withstand this stress (Maiti et al. 1976).

Thus, in birds, the role of adrenal cortex to counteract the dehydration stress is

\footnotetext{
Received 30 July 1990, Revised 31 July 1991, 2nd Revision 22 September 1992, Accepted 18 January 1993.

* Histophysiology Laboratory, Department of Zoology, University of Calcutta, 35 Ballygunge Circular Road, Calcutta 700 019, India.
} 
somewhat confusing and there is species variation in catecholamine response to water deprivation.

Again the maintenance of physiological homeostasis in dry environment depends on the effectiveness of osmoregulation and this functional mechanism is closely related to the habitat of any organism, its renal concentration ability and different hormonal milieu.

In view of this, for the present experiment two avian species-the pigeon and the house sparrow have been selected. Both of them share more or less similar habitat but they belong to diverse phylogeny.

\section{Materials and Methods}

The experimental specimens (i.e., 24 pigeons and 30 house sparrows) were collected from a local bird dealer and acclimatized in laboratory condition for five days. No mortality was observed in the pigeon, while two of the thirty house sparrows died during this period of acclimatization. The birds were then grouped into two:

Group I (Control) Food and water were given ad libitum throughout the experimental period. In group I, there were 8 pigeons and 8 house sparrows.

Group II (Treated) This group was deprived from water but food was given ad libitum. This group included 16 pigeons and 20 house sparrows.

The experiment was terminated when $50 \%$ mortality was noticed among the group II. It was the second day of the experiment in case of house sparrow, whereas the pigeons were sacrificed on the 8th day of the experiment. In group I, there was no mortality during the entire experimental tenure. Blood samples were collected from the wing-vein of the bird just after the termination of the experiments. Samples were centrifuged immediately after collection at 5,000 $\mathrm{g}$ for $3 \mathrm{~min}$. and plasma was drawn off. Plasma corticosterone concentration was then measured following the method of Glick et al. (1964). All the birds were killed by cervical dislocation and the adrenals were quickly taken out. These glands were either fixed in Bouin's fluid for histological studies or processed for biochemical quantitation of adrenomedullary catecholamines and adrenocorticoids following the method of Laverty and Taylor (1968) and Glick et al. (1964) respectively. Before quantitation, catecholamines were extracted from the adrenal medulla following the method of Nagatsu (1973).

The $5 \mu \mathrm{m}$ thick sections of adrenal gland were stained with haematoxylin-eosin and observed under the visible light microscope.

Each biochemical data is the mean \pm standard error.

The statistical analyses were done by Student's 't'-test (Snedecor and Cochran 1967).

\section{Results}

\section{Behavioral}

House sparrow. Dehydrated birds became droopy and less active and virtually abstained from taking any food.

Pigeon. Dehydrated birds consumed lesser quantity of food during this period 


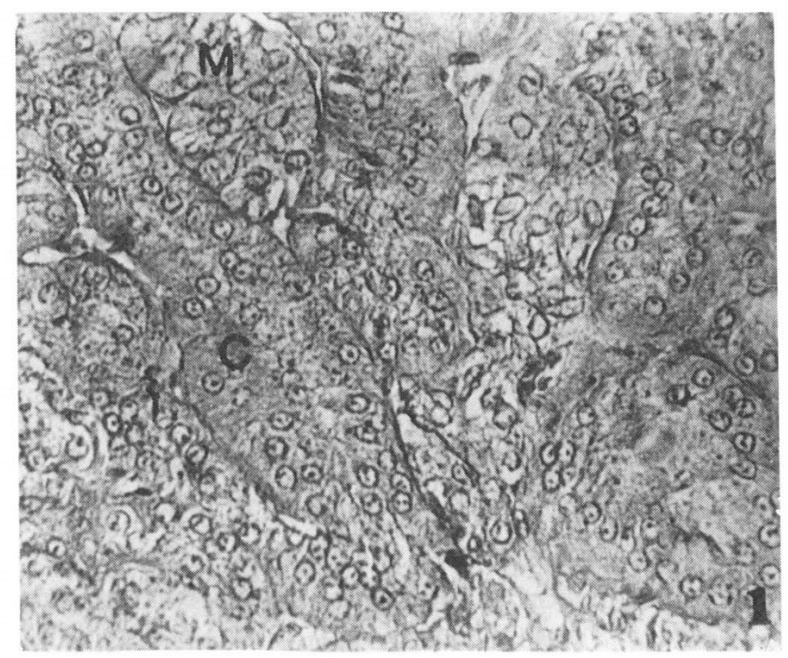

Fig. 1. Control. Note prominent fascicular cortical cords (with nuclei arranged along the basement membrane) intermingled with medullary patches (with randomly arranged nuclei).

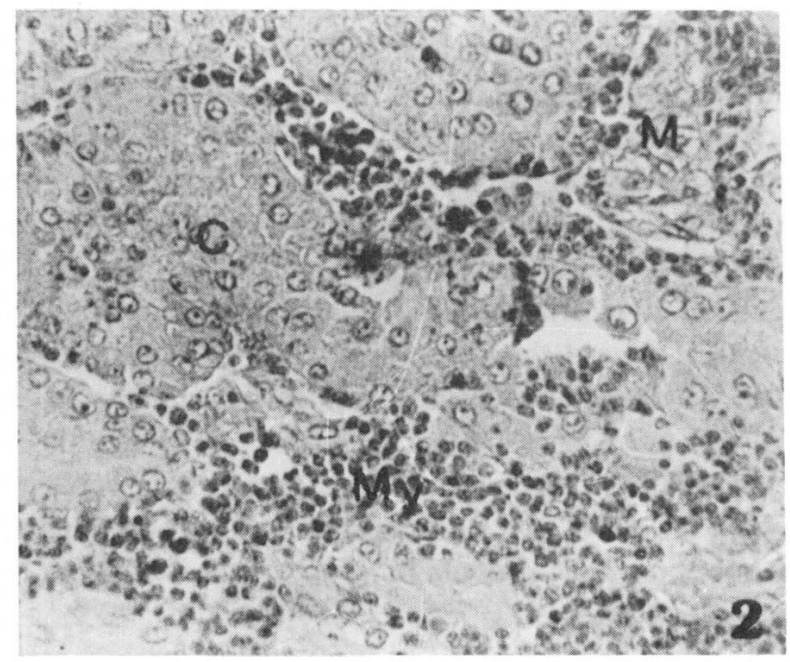

Fig. 2. Dehydrated. Observe compressed medullary lobule and abundant myeloid tissue. No noticeable change was found in the cortex.

C: Cortex; M: Medulla; My: Myeloid tissue

though no significant behavioral change was noticed among them.

Histological

House sparrow. No change was observed in the adrenal gland of the dehydrated house sparrow.

Pigeon. In the dehydrated pigeon, the medullary patches became slightly constricted while the third type of cells or myeloid cells were increased in number (Figs. 1 and 2). But 
no perceptible change was noticed in the cortex of the adrenal gland of the dehydrated bird.

\section{Biochemical}

The biochemical data on adrenomedullary catecholamines and corticosterone have been summarised in Text-figs. 1 and 2.

The data reveals that dehyration resulted in the decrease of both norepinephrine (NE) and epinephrine (E) contents from the adrenal medulla of the house sparrow while in the pigeon only epinephrine was depleted.

In the house sparrow, corticosterone concentration increased significantly in the adrenal gland following water deprivation. In the pigeon, dehydration caused increase of corticosterone concentration both in the gland as well as in the plasma. Since the amount of blood collected from the dehydrated sparrow was much less than the amount required for estimation of corticosterone, plasma corticosterone was not measured in the house sparrow.

\section{Discussion}

The findings reveal that dehydration caused release only $\mathrm{E}$ from the adrenal medulla of the pigeon. This indicates that $\mathrm{E}$ is possibly the stress hormone in the pigeon and it also agrees with that reported earlier in the pigeon (Ghosh and Sitaraman 1976) and in the Japanese quail (Kobayashi et al. 1980).

The results also indicated that in the house sparrow, both NE and $\mathrm{E}$ are depleted following dehydration. This points out that both the catechol hormones are required to counteract dehydration stress. Involvement of both the catechol hormones in counteracting stress situation has also been reported earlier in the dehydrated parakeet (Maiti et al. 1976).

Thus, the present findings indicate that dehydration-induced catecholamine change is not dependent on adrenomedullary hormonal milieu (e.g. $\mathrm{E}: \mathrm{NE}$ ratio in the pigeon is 43 : 57 in contrast to that of the house sparrow which is $95: 5$, cf. Ghosh, 1980).

It appears from the results (Text-Fig. 1c and 2c, 2d) that the response of corticosterone to the dehydration stress in both the pigeon and the house sparrow is similar.

Therefore the present as well as the previous reports indicate that barring the two phasianid species (Kobayashi et al. 1980; Arad et al. 1985), in the avian group, corticosterone is released to counteract the dehydration stress.

It seems difficult to infer what role corticosterone may have in the osmoregulatory mechanism. It was reported that hypovolaemia induced by dehydration increases plasma angiotensin II, which in turn stimulates adrenal cortex to release corticosterone (Kobayashi et al. 1980). Increased corticosterone possibly plays its role in osmoregulation in two different ways: (i) directly controlling salt-excretion as found in Zonotrichia leucophrys gambelli (Kawashima et al. 1964), presence of corticosterone receptors in the renal tubule of the duck (Charest-Boule' et al. 1980) further supports this view; (ii) stimulating AVT mediated water reabsorption.

Finally, it can be mentioned from the present findings that the pigeon is much more 


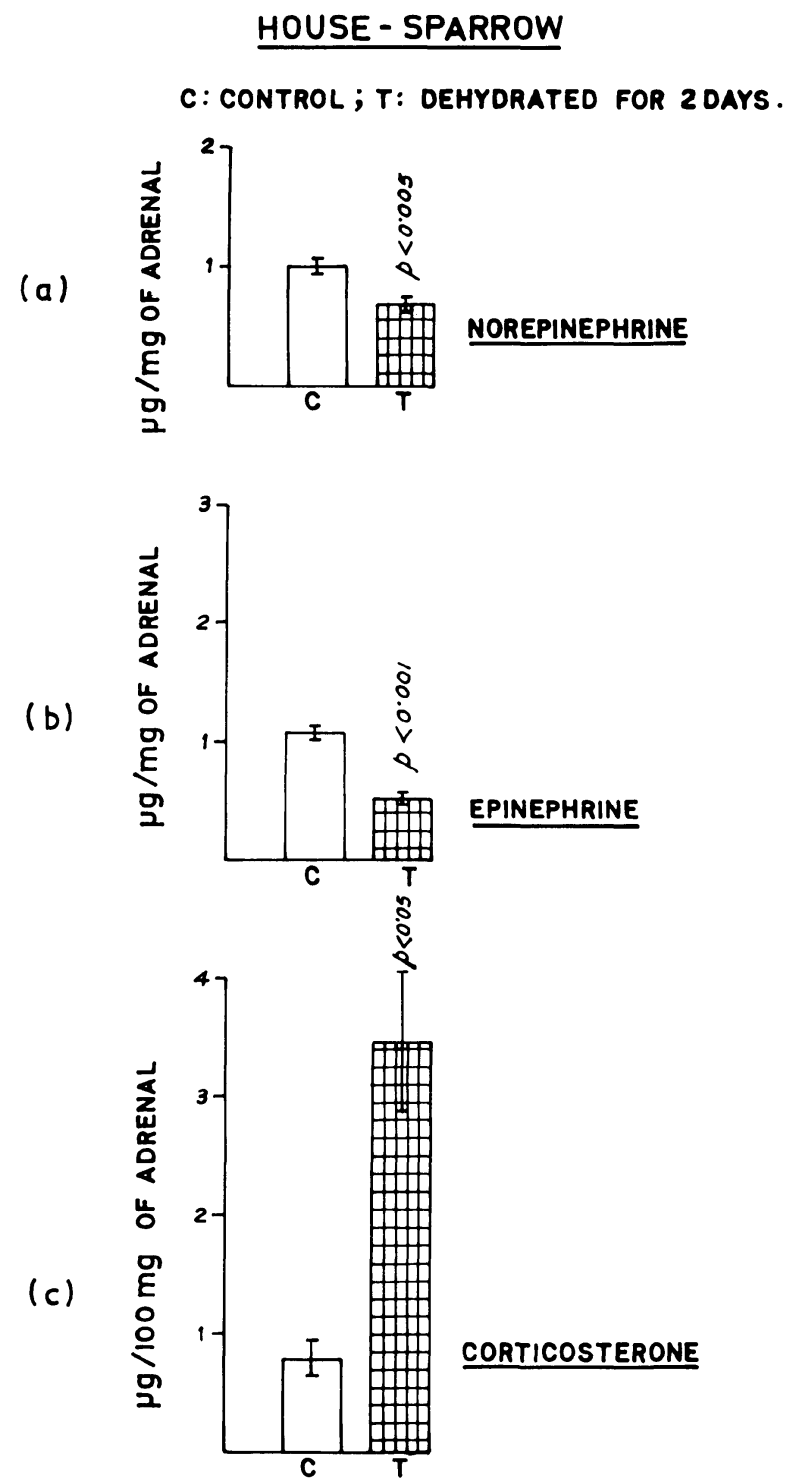

Text-Fig. 1(a). Dehydration for 2 days resulted in the depletion of norephinephrine from the adrenal gland of the house sparrow.

(b). Note dehydration-induced deplation of epinephrine form the adrenal gland of the house sparrow.

(c). Note increased corticosterone concentration in the adrenal gland of th dehydrated house sparrow. 


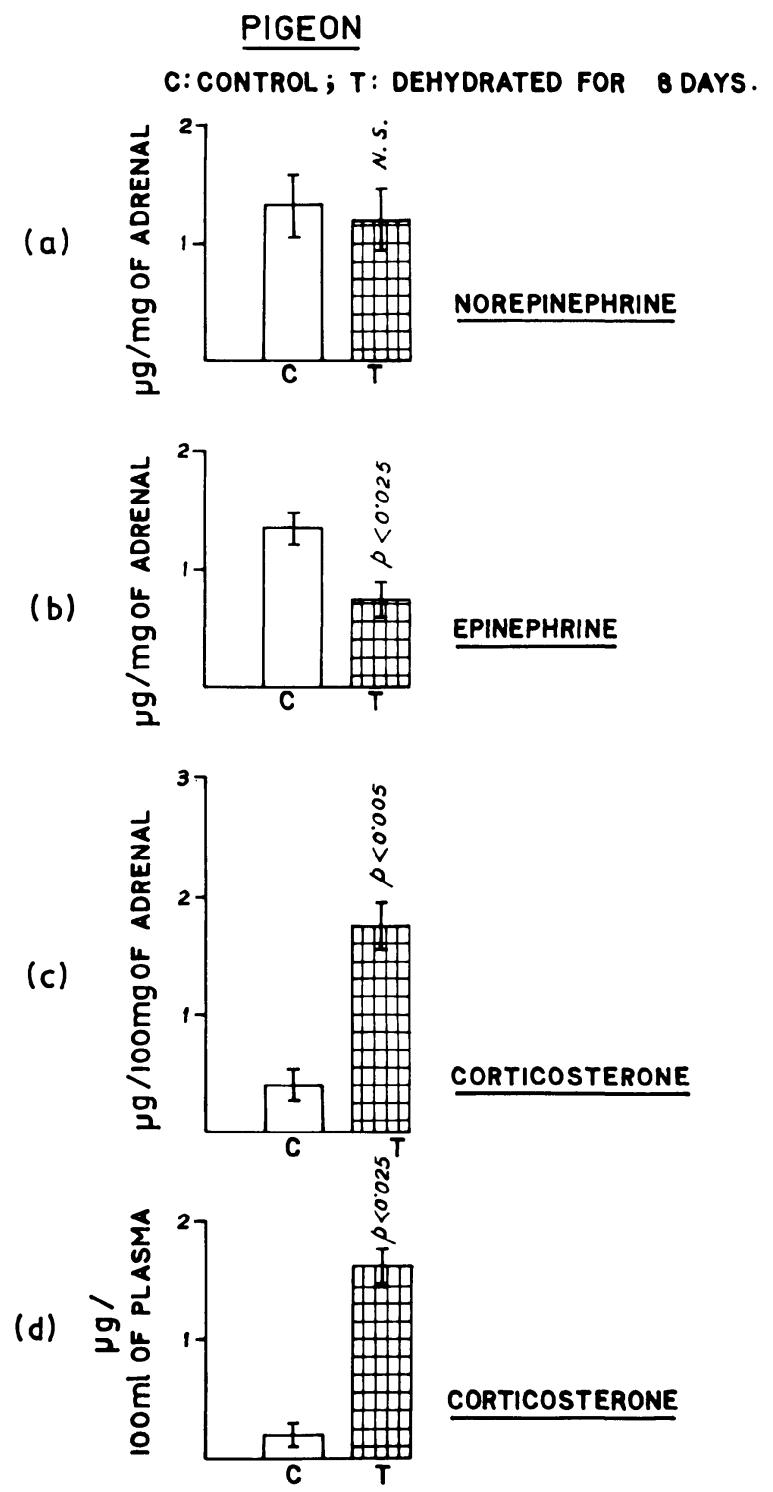

Text-Fig. 2(a). Dehydration for 8 days failed to alter norepinephrine content significantly in the pigeon.

(b). Note dehydration-induced depletion of epinephrine content from the adrenal gland of the pigeon.

(c). Note increased corticosterone concentration in the adrenal gland of the dehydrated pigeons.

(d). Note dehydration-induced increase in the plasma corticosterone concentration in the pigeon. 
resistant to dehydration stress than the house sparrow.

Whether such differences reflect the different phylogenetic status of these birds, difference in the reneal function or differential responsiveness of several other hormones like arginine vasotocin, prolactin and aldosterone (Arnason et al. 1986) in dehydration stress are yet to be determined.

\section{Acknowledgement}

This work has been supported by a grant from the Council of Scientific and Industrial Research [9/28/(152)/86-EMR-I dated 1987].

\section{References}

Arad, Z., Arnason, S. S., Chadwick, A. and Skadhauge, E. 1985. Osmotic and hormonal responses to heat and dehydration in the fowl. J. Comp. Physiol. B 155. 227-234.

Arnason, S. S., Rice, G. E., Chadwick, A. and Skadhauge, E. 1986. Plasma levels of arginine vasotocin, prolactin, aldosterone and corticosterone during prolonged dehydration in the domestic fowl; effect of dietary NaCl. J. Comp. Physiol. B 156: 383-397.

Beuving, G. and Vonder, G. M. A. 1978. Effect of stressing factors on corticosterone levels in plasma of laying hens. Gen. Comp. Endocrinol. 35: 153-159.

Charest-Boulě, L., Mehdi, A. Z. and Sandor. T. 1980. Corticosterone receptors in the avian kidney. J. Steroid Biochem. 13: 897-905.

Freeman, B. M. 1976. Stress and the domestic fowl: A physiological re-appraisal. World's Poult. Sci. J. 27: 263275.

Freeman, B. M., Manning, A. C. C. and Falck, I. H. 1983. Adrenal cortical activity in the domestic fowl, Gallus domesticus, following withdrawl of water or food. Comp. Biochem. Physiol. 74A: 639-641.

Ghosh, A. and Sitaraman, S. 1976. Effect of dehydration on the adrenal gland of the pigeon. Israel, J. Med. Sci. 12(9): 1122-1124.

Gray, G. D., Bergfors, A. M., Levin, R. and Levine, S. 1978. Comparison of the effects of restricted morning or evening water intake on adrenocortical activity in the female rats. Neuroendocrinology 25: 236-246.

Glick, D., Redlick, D. V. and Levine, S. 1964. Fluorometric determination of corticosterone and cortisol in 0.02-0.05 ml. of plasma or submilligram samples of adrenal tissue. Endocrinology 74: 653-655.

Harvey, S., Klandorf, H. and Phillips, J. G. 1981. Effects of food or water deprivation on circulating levels of pituitary, thyroid and adrenal hormones and on glucose and electrolyte concentrations in domestic ducks (Anas platyrhynchos). J. Zool. 194: 341-361.

Harvey, S., Klandorf, H. and Lam, S. K. 1985. Drinking-induced changes in fowl adrenocortical activity: effect of visual and non-visual stimuli. J. Endocrinol. 104: 225-231.

Johnson, J. T. and Levine, S. 1978. Influence of water deprivation on adrenocortical rhythms. Neuroendocrinology II: $268-273$.

Kawashima, S., Farner, D. S., Kobayashi, H., Oksche, A. and Lorenzen, L. 1964. The effect of dehydration on acid phosphatase activity, catheptic-proteinase activity and neurosecretion in the hypothalamo-hypophyseal system of white crowned sparrow, Zonotrichia leucophrys gambelli. Z. Zellforsch. 62: 141-181.

Kobayashi, H., Uemura, H. and Takei, Y. 1980. Physiological role of the renin-angiotensin system in dehydration. In "Avian Endocrinology" (A. Epple and M. H. Stetson, eds.). pp. 319-330. Academic Press, New York.

Laverty, R. and Taylor, K. M. 1968. The fluorometric assay of catecholamines and related compounds: Improvements and extensions to the hydroxyindole technique. Anal. Biochem. 22: 269-279.

Levine, S. and Coover, G. D. 1976. Environmental control of suppression of the pituitary-adrenal system. 
Physiol. Behav. 17: 35-37.

Maiti, B. R., Ray, D. and Ghosh, A. 1976. Neurohypophysial-adrenal gland responses to water-deprivation in the Rose-ringed parakeet. Z. Mikrosk. anat. Forsch., Leipzig 90: 175-183.

Nagatsu, T. 1973. Biochemistry of catecholamines. In 'The Biochemical Method'. University Park Press. Baltimore, London, Tokyo, pp. 231.

Snedecor, G. W. and Cochran, W. G. 1967. 'Statistical Methods' 6th edition, pp. 432. Iowa State Univ. Press, Ames, Iowa.

Wilkinson, C. W., Shinsako, J. and Dallman, M. F. 1982. Rapid decrease in adrenal and plasma corticosterone concentration after drinking are not mediated by changes in plasma adrenocortical concentration. Endocrinology 110: 1599-1606.

\section{脱水によるストレスが半家离 2 種（ドバトとイエスズメ） の副腎に与える影響}

脱水が，半家禽化された 2 種の鳥類，ドバトとイエスズメの副腎によ゙のような影響を与えるかを調べた。 イエスズメでは, 脱水による副腎の組織学的な变化は見られなかったが, ドバトでは㖪質部が退縮し, 骨㖪 球様組織が增加した。一方，イエスズメにおいては脱水によりノルエピネフリン $(34 \%)$, エピネフリン (50\%) とも副腎骫質中の含量が隇少したのに対して, ドバトではエピネフリン $(45 \%)$ のみが咸少した。副 腎中のコルチコステロンはドバト (375.7\%) でむイエスズメ (336.7\%) でも增加した。今回の実験により， 脱水によるストレスにはコルチコステロンの関与は鳥類で普遍的であるが，カテコールホルモンには, $\mathrm{NE}: \mathrm{E}$ 比とは独立して, 種による反応の違いがあることが示された。この反応の違いを説明するためには, 腎葴の生理学的状態や他のホルモンのことを考慮しなければならないだろう。

Kakali De and Asok Ghosh: カルカッタ大学動物学科組織生理学教室 